\title{
An audit on the knowledge, beliefs and attitudes about the uses and side-effects of antibiotics among outpatients attending 2 teaching hospitals in Jordan
}

\author{
K. Alzoubi, ${ }^{1}$ S. Al-Azzam, ${ }^{1}$ A. Alhusban, ${ }^{1}$ T. Mukattash, ${ }^{7}$ S. Al-Zubaidy, ${ }^{2}$ N. Alomari ${ }^{3}$ and Y. Khader ${ }^{4}$
}

$$
\begin{aligned}
& \text { در استة تدقيقيّة في المعارف والمعتقدات والمو اقفت المتعلّقة باستخدامات المضادات الحيوية وتأثير اتها الجانبية لدى المرضى الحارجيين }
\end{aligned}
$$

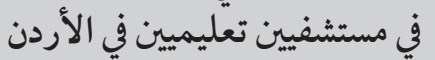

$$
\begin{aligned}
& \text { كريم الزعبي، ساير العزام، أحمد الحسبان، طاردين لارق مقطش، سامح الزبيدي، ناديا العمري، يوسف خضر }
\end{aligned}
$$

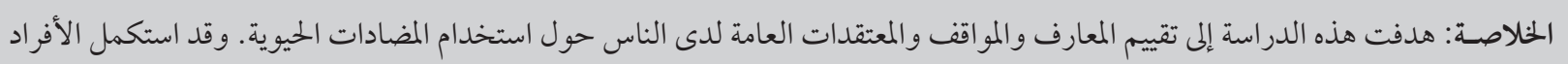

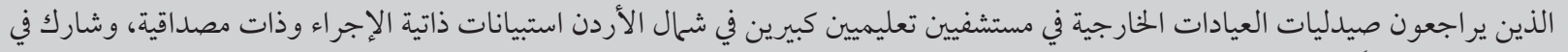

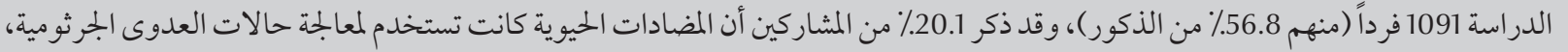

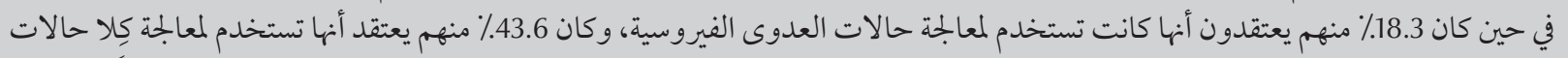

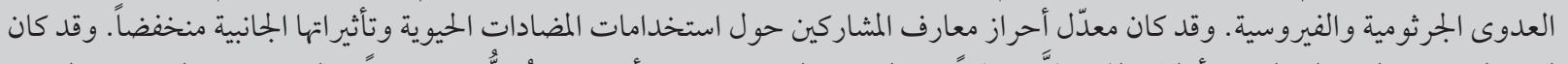

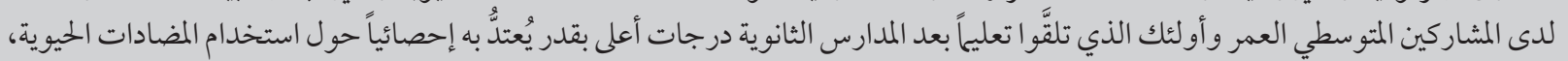

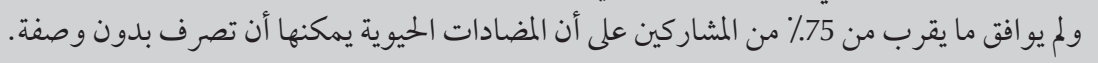

ABSTRACT This study aimed to assess general knowledge, beliefs and attitudes of people towards the use of antibiotics. Individuals referring to the outpatient pharmacies of 2 major teaching hospitals in the north of Jordan completed a self-administered, validated questionnaire. A total of 1091 individuals (56.8\% males) participated in the study. Of these, $20.1 \%$ of the participants stated that antibiotics were used for bacterial infections, while $18.3 \%$ thought they were used for viral infections and $43.6 \%$ for mixed bacterial/viral infections. The average knowledge score of the participants about antibiotic uses and side-effects was low. Middle-aged participants and those with an education beyond high school had significantly higher knowledge scores about antibiotics use. Almost 75\% of the participants disagreed that antibiotics could be given without a prescription.

Évaluation des connaissances, croyances et attitudes concernant l'utilisation et les effets secondaires des antibiotiques chez des patients en consultation externe dans deux hôpitaux universitaires en Jordanie

RÉSUMÉ La présente étude visait à évaluer les connaissances, les croyances et les attitudes générales concernant I'utilisation des antibiotiques. Les patients qui se sont adressé aux pharmacies des services des consultations externes de deux grands hôpitaux universitaires dans le nord de la Jordanie ont rempli un auto-questionnaire validé. Au total, 1091 patients (dont 56,8 \% de sexe masculin) ont participé à l'étude. Parmi ceux-ci, 20,1\% des participants ont indiqué que les antibiotiques étaient prescrits pour lutter contre des infections bactériennes, tandis que 18,3\% pensaient qu'ils étaient destinés à combattre des infections virales et 43,6 \% qu'ils étaient utilisés contre des infections mixtes virales et bactériennes. Le score moyen des connaissances des participants sur l'utilisation des antibiotiques et leurs effets secondaires était faible. Les participants d'un âge intermédiaire ainsi que ceux ayant suivi des études supérieures ont obtenu des scores nettement plus élevés concernant I'utilisation des antibiotiques. Près de $75 \%$ des participants n'étaient pas d'accord avec l'affirmation selon laquelle des antibiotiques pouvaient être dispensés sans ordonnance.

${ }^{7}$ Department of Clinical Pharmacy, Faculty of Pharmacy; ${ }^{4}$ Department of Community Medicine, Faculty of Medicine, Jordan University of Science and Technology, Irbid, Jordan (Correspondence to K. Alzoubi: khalzoubi@just.edu.jo).

${ }^{2}$ Department of Biopharmaceutics and Clinical Pharmacy, Faculty of Pharmacy, University of Jordan, Amman, Jordan.

${ }^{3}$ Royal Medical Services, Amman, Jordan.

Received: 08/07/11; accepted: 12/12/11 


\section{Introduction}

Antibiotic resistance is now recognized as a global public health problem with major economic, social and political implications according to the World Health Organization (WHO) [1]. There have been prior reports that more than $70 \%$ of the bacteria associated with hospital-acquired infections in the United States of America (USA) are resistant to 1 or more of the drugs previously used to treat them [2]. Fure thermore, the WHO states that $45 \%$ of deaths in low-income countries are due to infectious causes such as pneumonia, diarrhoea, and tuberculosis [1]. It has been reported that nearly 2 million patients in the USA get an infection in hospital each year, and about 90000 die each year as a result of their infection [2].

Many factors are implicated in the emergence of bacterial resistance to antibiotics. One of these is the over-use and misuse of antibiotics, which merit special attention as there are many types. These include self-medication with antibiotics, which is an important problem in many countries, for example Turkey, Poland, Sudan and Jordan [3-7]. Although self-medication is perceived as a hazard to health, people with no health insurance may try to avoid paying for the services of the general practitioner and for laboratory tests by going directly to a pharmacy. This practice is very common in Jordan [3] despite the fact that the Jordanian Drug and Pharmacy Law classes dispensing antibiotics of any formulation without a prescription as a criminal offence, and violators are subject to a financial penalty. It is thought that competition among pharmacies could be the reason for such practices, despite any existing legislation $[8,9]$. However, accessibility to antibiotics as prescription-only-medications does not exclude the possibility of using them as self-medication. For example, antibiotics can be obtained as leftovers from incomplete courses of treatment or may be supplied by friends or relatives. Some patients insist on the physician prescribing antibiotics. For example, in response to pressure from parents believing in the need for antibiotic treatment, paediatricians sometimes agree to prescribe antibiotics for their children [10].

According to the WHO, lack of education about the prudent use of antibiotics was one of the factors that affected the use of antibiotics [1]; many studies have, in fact, confirmed the positive effects of educational campaigns on the use of antibiotics [11-13].

The different ways of accessing antibiotics is an important factor with regard to education. In our country, where antibiotics are mostly accessed without prescription despite the presence of a law that bans such practices, it would be important carry out public educational campaigns. In order to prepare an effective public education programme, knowledge about the most important points to tackle is imperative.

Thus, in this study, we evaluated the knowledge, beliefs and attitudes of the public toward antibiotic use.

\section{Methods}

Patients referred to the outpatient pharmacy of 2 major teaching hospitals (King Abdullah University Hospital and Princess Basma Teaching Hospital) covering the population in the northern province of Jordan were assessed. These hospitals receive patients representing all levels of society. This study took place between March 2008 and May 2008 and patients were recruited on a daily basis. Patients were given a description of the study and its goals, and were asked to participate. Excluded from the study were those who had a medical education-related degree such as physicians, pharmacists, dentists, nurses, and all supporting medical degrees ad patients under 18 years old.
Those who agreed to participate were asked to complete and sign an informed consent form, and to complete a self-administered questionnaire while waiting to fill their prescriptions. Investigators were available to answer participants' questions during they were completing the questionnaire. The study was approved by the institutional review board of Jordan University of Science and Technology.

The questionnaire used in the study was prepared by the research team, and was validated by first having it reviewed by several colleagues in the field, then by conducting a pilot test on 20 people recruited from the outpatient pharmacy referral pool of both hospitals; they were not part of the study sample. The results were analysed to assess the clarity and the comprehensibility of the items on the questionnaire. In addition, the participants of the pilot study were asked to give any feedback they had about the questionnaire items. Their feedback was considered in preparing the final version of the questionnaire.

The questionnaire had 3 parts: the first part covered the demographic data of the participants. The second contained items asking about the nature of antibiotics use, and attitudes of participants toward the use of antibiotics in a number of minor ailments such as common cold and flu, cough, diarrhoea, etc., for which antibiotics are often misused. Additionally, participants were asked if antibiotics should be used for protection from infections, if they can be used without prescription, and if they should be continued after symptoms of the infection have resolved. In the third part of the questionnaire, participants were asked about common side-effects of antibiotics, and whether antibiotics could lead to health risks when used with other medications.

To generate the participants' knowledge data, items assessing knowledge and beliefs about antibiotics were recoded according to the response: each correct response was assigned 1 point 
while wrong responses were assigned 0 points. Then, the sum of the responses for each participant was calculated, and placed on a scale of $1-100$.

Sample size was based on previous studies on the same population $[14,15]$. Demographic data and categorical variables were summarized using frequency tables. Statistical analysis was performed using SPSS, version 15. $P<0.05$ was considered significant.

\section{Results}

During the study period, 1138 patients were invited to participate in the study and 1091 (95.9\%) agreed. Table 1 shows the demographic characteristics of the participants. They were similarly distributed according to age; $56.8 \%$ were males, and $52.2 \%$ were educated to at least university or community college level. More than half (57.2\%) had an income $<250$ Jordanian dinars. About one-third (35.6\%) were living in villages.

The study sample had generally poor knowledge about the type or nature of infections or medical conditions for which antibiotics are used. Only $20.1 \%$ of participants believed that antibiotics are used for bacterial infections, while $18.3 \%$ thought that antibiotics were used for viral infections and $43.6 \%$ thought they were used for mixed bacterial/viral infections (Table 2). Almost $80 \%$ of participants thought that antibiotics could be used for common cold and flu sometimes/most of the time/ always. When asked if antibiotics can be used for protection from infections, only $39.3 \%$ disagreed. Just under $75 \%$ disagreed with giving antibiotics without prescription, and over $70 \%$ agreed/ strongly agreed that antibiotic use must be continued even after symptoms resolve.

In assessing knowledge of patients about the most common side-effects of antibiotics, many of the participants did not think that antibiotics caused

\begin{tabular}{|c|c|c|}
\hline Demographic characteristic & No. & $\%$ \\
\hline \multicolumn{3}{|l|}{ Age (years) } \\
\hline 18-30 & 481 & 44.1 \\
\hline $31-40$ & 241 & 22.1 \\
\hline $41-50$ & 134 & 12.3 \\
\hline $51-70$ & 235 & 21.5 \\
\hline \multicolumn{3}{|l|}{ Sex } \\
\hline Male & 620 & 56.8 \\
\hline Female & 471 & 43.2 \\
\hline \multicolumn{3}{|l|}{ Education level } \\
\hline$\leq$ High school & 522 & 47.8 \\
\hline > High school & 569 & 52.2 \\
\hline \multicolumn{3}{|l|}{ Profession } \\
\hline None & 276 & 25.3 \\
\hline Housewife & 197 & 18.1 \\
\hline Teacher & 145 & 13.3 \\
\hline Craftsman & 77 & 7.1 \\
\hline Engineer & 55 & 5.0 \\
\hline Merchant & 86 & 7.9 \\
\hline Other & 255 & 23.4 \\
\hline \multicolumn{3}{|l|}{ Monthly income (JD) } \\
\hline$\leq 250$ & 624 & 57.2 \\
\hline$>250$ & 467 & 42.8 \\
\hline \multicolumn{3}{|l|}{ Residence } \\
\hline Rural & 388 & 35.6 \\
\hline Urban & 703 & 64.4 \\
\hline
\end{tabular}

$J D=$ Jordanian dinar $(J D 1 \approx$ US\$1.4).

side-effects or did not know that they caused side-effects (Table 3): the proportion disagreeing or who did not know ranged from $32.1 \%$ for "antibiotics can cause skin rash" to $70.1 \%$ for "antibiotics can impair bone growth". On the other hand, $62.9 \%$ of the participants knew about the health risks of concomitant use of antibiotics with other medications (Table 3).

The mean knowledge score of the participants on a $1-100$ scale was 39.6 (standard deviation 17.8), which is quite low. When assessed according to the demographic factors, knowledge scores were significantly affected by age and level of education $(P<0.05$ for both) (Table 4). Other demographic factors, including sex, profession, monthly income and place of residence, had no statistically significant effect.

\section{Discussion}

The current study is the first to assess the knowledge, attitudes and beliefs of the Jordanian population about antibiotic use. Results of previous studies have shown there is a high percentage of selfmedication with antibiotics $[3,4,16]$. In a recent study, antibiotics were listed by pharmacists among the top drugs that they suspected of being misused/ abused by the public in Jordan [17].

The average knowledge score of the sample was low. This finding is further supported by the high proportion of participants thinking antibiotics are useful for the common cold, sore throat and the other minor ailments, thus showing the general lack of knowledge about this domain. These results agree with the findings of recent large cross-sectional 
Table 2 Knowledge of participants of the use of antibiotics $(n=1091)$

Knowledge point

No.

Antibiotics are used for:

Bacterial infections

Viral infections

Mixed infections

Do not know

Antibiotics can be used when you have symptoms of common cold or flu

Always

Most of the time

Sometimes

Rarely

Never

Do not know

Antibiotics can be used for sore throat

Always

Most of the times

Sometimes

Rarely

Never

Do not know

Antibiotics can be used when you have cough

Always

Most of the times

Sometimes

Rarely

Never

Do not know

Antibiotics can be used when you have fever

Always

Most of the times

Sometimes

Rarely

Never

Do not know

114

Antibiotics can be used when you have diarrhoea

Always

Most of the times

Rarely

Never

Antibiotics can be used to protect against infections

Strongly agree

Agree

Do not know

Antibiotics can be given without prescription

Strongly agree

Agree

Do not agree

Do not know

Antibiotics should be continued if symptoms resolved

Strongly agree

Agree 


\begin{tabular}{|c|c|c|}
\hline Knowledge point & No. & $\%$ \\
\hline \multicolumn{3}{|c|}{ Antibiotics can lead to shock } \\
\hline Strongly agree & 141 & 12.9 \\
\hline Agree & 281 & 25.8 \\
\hline Do not agree & 191 & 17.5 \\
\hline Do not know & 478 & 43.8 \\
\hline \multicolumn{3}{|c|}{ Antibiotics can cause skin rash } \\
\hline Strongly agree & 204 & 18.7 \\
\hline Agree & 537 & 49.2 \\
\hline Do not agree & 69 & 6.3 \\
\hline Do not know & 281 & 25.8 \\
\hline \multicolumn{3}{|c|}{ Antibiotics can cause gastrointestinal upset } \\
\hline Strongly agree & 175 & 16.0 \\
\hline Agree & 492 & 45.1 \\
\hline Do not agree & 96 & 8.8 \\
\hline Do not know & 328 & 30.1 \\
\hline \multicolumn{3}{|c|}{ Antibiotics can cause oral fungal infections } \\
\hline Strongly agree & 69 & 6.3 \\
\hline Agree & 351 & 32.2 \\
\hline Do not agree & 211 & 19.3 \\
\hline Do not know & 460 & 42.2 \\
\hline \multicolumn{3}{|c|}{ Antibiotics can cause gastrointestinal infections } \\
\hline Strongly agree & 77 & 7.1 \\
\hline Agree & 413 & 37.9 \\
\hline Do not agree & 194 & 17.8 \\
\hline Do not know & 407 & 37.3 \\
\hline \multicolumn{3}{|c|}{ Antibiotics can cause renal damage } \\
\hline Strongly agree & 148 & 13.6 \\
\hline Agree & 462 & 42.3 \\
\hline Do not agree & 114 & 10.4 \\
\hline Do not know & 367 & 33.6 \\
\hline \multicolumn{3}{|c|}{ Antibiotics can discolour the teeth } \\
\hline Strongly agree & 107 & 9.8 \\
\hline Agree & 310 & 28.4 \\
\hline Do not agree & 217 & 19.9 \\
\hline Do not know & 457 & 41.9 \\
\hline \multicolumn{3}{|c|}{ Antibiotics can impair bone growth } \\
\hline Strongly agree & 75 & 6.9 \\
\hline Agree & 252 & 23.1 \\
\hline Do not agree & 195 & 17.9 \\
\hline Do not know & 569 & 52.2 \\
\hline \multicolumn{3}{|c|}{ Antibiotics can lead to health risks when used with other medications } \\
\hline Strongly agree & 178 & 16.3 \\
\hline Agree & 508 & 46.6 \\
\hline Do not agree & 120 & 11.0 \\
\hline Do not know & 285 & 26.1 \\
\hline
\end{tabular}




\begin{tabular}{|c|c|c|}
\hline Factor & Mean (SD) knowledge score & $P$-value \\
\hline \multicolumn{3}{|l|}{ Age (years) } \\
\hline 18-30 & $38.9(18.1)$ & \multirow{4}{*}{0.003} \\
\hline $31-40$ & $36.8(16.6)$ & \\
\hline $41-50$ & $42.3(17.5)$ & \\
\hline $51-70$ & $42.0(18.2)$ & \\
\hline \multicolumn{3}{|l|}{ Sex } \\
\hline Male & 39.5 (17.9) & \multirow[t]{2}{*}{0.837} \\
\hline Female & $39.7(17.6)$ & \\
\hline \multicolumn{3}{|l|}{ Education level } \\
\hline$\leq$ High school & $36.45(16.5)$ & \multirow[t]{2}{*}{$<0.001$} \\
\hline$>$ High school & $42.37(18.5)$ & \\
\hline \multicolumn{3}{|l|}{ Profession } \\
\hline None & $40.0(18.4)$ & \multirow[t]{7}{*}{0.257} \\
\hline Housewife & 37.1 (16.3) & \\
\hline Teacher & $40.8(16.1)$ & \\
\hline Crafts man & $37.5(18.0)$ & \\
\hline Engineer & $40.2(15.9)$ & \\
\hline Merchant & $38.8(18.6)$ & \\
\hline Other & $41.1(19.2)$ & \\
\hline \multicolumn{3}{|c|}{ Monthly income (JD) } \\
\hline$\leq 250$ & $39.2(17.6)$ & \multirow[t]{2}{*}{0.092} \\
\hline$>250$ & $42.0(19.1)$ & \\
\hline \multicolumn{3}{|l|}{ Residence } \\
\hline Urban & $40.3(18.0)$ & \multirow[t]{2}{*}{0.192} \\
\hline Rural & $38.3(17.6)$ & \\
\hline
\end{tabular}

$S D=$ standard deviation $; D=$ Jordanian dinar $(J D 1 \approx$ US\$1.4).

studies conducted in the United Kingdom, which show that around 30\%-38\% of the sample thought that antibiotics were effective for common cold and cough. The level of knowledge demonstrated among the British sample is, however, much better than that among our sample with regard to this item $[18,19]$. In a Swedish study only $19.1 \%$ agreed that antibiotics can be used to cure common colds [20]. This higher knowledge can be attributed in part to the multiple educational campaigns conducted in these countries [21]. In another study from Hong Kong, 26\% of the sample believed that antibiotics were needed for symptoms of upper respiratory tract infections if they felt sick enough to seek medical care [22].Conversely, in a study carried out on patients visiting clinics in New York, 70\% though that antibiotics antibiotics ranged from $2 \%$ to $35 \%$, with an overall prevalence of $10 \%$ [25]. In a recent cross-sectional public survey in Syria, only $43 \%$ were prescribed the antibiotic by a physician to treat the condition, while $57 \%$ used an old prescription or took someone else's advice [24]. In Egypt, $24 \%$ of mothers attending the outpatient clinic of Ain Shams University Paediatric Hospital prescribed antibiotics to their children [26]. Recent studies from Jordan have reported a self-medication rate with antibiotics of about $40 \%[4,16]$.

Public education campaigns have been shown to be a successful tool for raising public awareness about antibiotics $[12,27,28]$. Other studies, however, have found that public awareness campaigns about antibiotics had no effect on the level of knowledge or the types of interventions desired by participants $[21,29]$. In that respect, a recent study from Jordan reported varying level of awareness of bacterial resistance among health-care professionals [30], which indicates, taken with the results of the current study, the urgent need for serious educational efforts for both the public and the medical professionals. Educational programmes could take several forms, including brochures and posters, public lectures and seminars, public media such as television, radio and social networks on the Internet, to post advertisements, programmes and lectures encouraging the proper use of antibiotics.

This study was limited to individuals referred to the hospitals where the study was conducted. More males were included in the study than females, which was not under our control as there was no intention to recruit higher numbers of either sex. The study did not assess whether the participants perceived the possible complications of antibiotic resistance.

On the other hand, this study, addressed the main points that merit attention when knowledge about antibiotic is the concern. It addressed knowledge about the different indications for prescribing antibiotics plus their side-effects. It also assessed how willing the participants were to 
self-medicate with antibiotics. As a result, this study provides decision-makers with important information about which areas of knowledge about antibiotics to target when preparing an educational campaign about the use of antibiotics.

Our findings showed a low level of knowledge among the sample population, which indicates there is a need for the establishment of a national educational campaign that focuses on the proper use of antibiotics for minor ailments. In addition, information about the complications associated with antibiotic resistance should be included in these educational campaigns. Stronger legal restrictions should be introduced on the selling of antibiotics in community pharmacies.

\section{Acknowledgements}

We would like to thank Jordan University of Science and Technology for their support.

Funding: This projected was supported by Jordan University of Science and Technology.

Competing interests: None declared.

\section{References}

1. Report on infectious diseases. Removing obstacles to healthy development. Geneva, World Health Organization, 1999 (http:// www.who.int/infectious-disease-report/index-rpt99.html, accessed 5 March 2013).

2. Bad bugs, no drugs: as antibiotic R\&D stagnates, a public health crisis brews. Alexandria, Virginia, Infectious Diseases Society of America, 2004.

3. Al-Bakri AG, Bustanji Y, Yousef AM. Community consumption of antibacterial drugs within the Jordanian population: sources, patterns and appropriateness. International Journal of Antimicrobial Agents, 2005, 26(5):389-395.

4. Al-Azzam SI et al. Self-medication with antibiotics in Jordanian population. International Journal of Occupational Medicine and Environmental Health, 2007, 20(4):373-380.

5. Buke $\mathrm{C}$ et al. Irrational use of antibiotics among university students. Journal of Infection, 2005, 51(2):135-139.

6. Olczak A et al. Leczenie antybiotykami bez konsultacji lekarskiej w Polsce [Self-medication with antibiotics in Poland]. Polski Merkuriusz Lekarski, 2006, 20(116):151-154.

7. Awad AI, Eltayeb IB, Capps PA. Self-medication practices in Khartoum State, Sudan. European Journal of Clinical Pharmacology, 2006, 62(4):317-324.

8. Borg MA, Scicluna EA. Over-the-counter acquisition of antibiotics in the Maltese general population. International Journal of Antimicrobial Agents, 2002, 20: (4)253-257.

9. Svensson E, Haaijer-Ruskamp FM, Lundborg CS. Self-medication with antibiotics in a Swedish general population. Scandinavian Journal of Infectious Diseases, 2004, 36(6-7):450-452.

10. Li LJ, Wang PS. Self-medication with antibiotics: a possible cause of bacterial resistance. Medical Hypotheses, 2005, 65(5):1000-1001.

11. Wutzke SE et al. Evaluation of a national programme to reduce inappropriate use of antibiotics for upper respiratory tract infections: effects on consumer awareness, beliefs, attitudes and behaviour in Australia. Health Promotion International, 2007, 22(1):53-64.

12. Trepka MJ et al. The effect of a community intervention trial on parental knowledge and awareness of antibiotic resistance and appropriate antibiotic use in children. Pediatrics, 2001, 107(1):E6.

13. Curry $M$ et al. Public views and use of antibiotics for the common cold before and after an education campaign in New Zealand. New Zealand Medical Journal, 2006, 119(1233):U1957.

14. Mukattash TL et al. Public knowledge and awareness of cardiovascular disease and its risk factors: a cross-sectional study of 1000 Jordanians. International Journal of Pharmacy Practice, 2012, 20(6):367-376

15. Wazaify $M$ et al. Societal perspectives on over-the-counter (OTC) medicines. Family Practice, 2005;22(2):170-176.

16. Sawair FA et al. Assessment of self-medication of antibiotics in a Jordanian population. Medical Principles and Practice, 2009, 18(1):21-25.
17. Albsoul-Younes A et al. Abuse and misuse of prescription and nonprescription drugs sold in community pharmacies in Jordan. Substance Use \& Misuse, 2010, 45(9):1319-1329.

18. McNulty CA et al. Don't wear me out-the public's knowledge of and attitudes to antibiotic use. Journal of Antimicrobial Chemotherapy, 2007, 59(4):727-738.

19. Smith GE et al. What has happened to antimicrobial usage in primary care in the United Kingdom since the SMAC report? description of trends in antimicrobial usage using the General Practice Research Database. Journal of Public Health, 2004, 26(4):359-364.

20. André $\mathrm{M}$ et al. A survey of public knowledge and awareness related to antibiotic use and resistance in Sweden. Journal of Antimicrobial Chemotherapy, 2010, 65(7):1292-1296.

21. McNulty CA et al. The English antibiotic awareness campaigns: did they change the public's knowledge of and attitudes to antibiotic use? Journal of Antimicrobial Chemotherapy, 2010, 65:1526-1533

22. You JH et al. Public knowledge, attitudes and behavior on antibiotic use: a telephone survey in Hong Kong. Infection, 2008, 36(2):153-157.

23. Filipetto FA et al. Patient knowledge and perception of upper respiratory infections, antibiotic indications and resistance. Patient Preference \& Adherence, 2008, 2:35-39.

24. Barah F, Gonçalves V. Antibiotic use and knowledge in the community in Kalamoon, Syrian Arab Republic: a crosssectional study. Eastern Mediterranean Health Journal, 2010, 16(5):516-521.

25. Grigoryan L et al.; SAR consortium. Attitudes, beliefs and knowledge concerning antibiotic use and self-medication: a comparative European study. Pharmacoepidemiology and Drug Safety, 2007, 16(11):1234-1243.

26. Aboul Fotouh AM, el-Damaty SE, Abdel Megeid FY. Mother's knowledge about antibiotic and role of self prescription. Journal of the Egyptian Public Health Association, 1998, 73(12):57-69.

27. Shah BK. Knowledge that upper respiratory tract infection resolves on its own is associated with more appropriate healthseeking behaviour and antibiotic cognition. Singapore Medical Journal, 2006, 47(11):1012.

28. Croft DR et al. Impact of a child care educational intervention on parent knowledge about appropriate antibiotic use. WMJ: Official Publication of the State Medical Society of Wisconsin, 2007, 106(2):78-84.

29. Huang SS et al. Parental knowledge about antibiotic use: results of a cluster-randomized, multicommunity intervention. Pediatrics, 2007, 119(4):698-706.

30. Alzoubi K et al .Awareness of bacterial resistance among physicians, pharmacists and nurses. International Journal of Occupational Medicine and Environmental Health, 2009, 22:363-372. 